\title{
PRELIMINARY RESEARCH REGARDING CHEMICAL COMPOSITION AND ANTI-INFLAMMATORY EFFECTS OF POLYGONUM PLEBEIUM R. BR
}

\author{
HASEEB AHSAN $^{1 *}$, MUHAMMAD NAVEED MUSHTAQ $^{2}$, IRFAN ANJUM ${ }^{2}$, MUHAMMAD \\ FIAZ $^{3}$, AHMED RAZA CHEEMA ${ }^{4}$, SYED IHTISHAM HAIDER ${ }^{5}$, GEBRETSADKAN HINTSA \\ TEKULU $^{6}$
}

\author{
${ }^{I}$ Department of Pharmacology, Faculty of Pharmacy, University of Sargodha, Pakistan \\ ${ }^{2}$ Department of Pharmacology, Faculty of Pharmacy, The University of Lahore, Pakistan \\ ${ }^{3}$ Faculty of Pharmacy and alternative medicine, The Islamia University of Bahawalpur, Pakistan \\ ${ }^{4}$ Department of Economics, Faculty of Social Sciences, University of Sargodha, Pakistan \\ ${ }^{5}$ Department of Pharmacology, Nawaz. Sharif Medical College, University of Gujrat, Pakistan \\ ${ }^{6}$ Department of Pharmacognosy, School of Pharmacy, College of Health Sciences, Mekelle University, P.O. Box 1871, \\ Mekelle, Ethiopia
}

*corresponding author: haseeb.ahsan@uos.edu.pk

Manuscript received: December 2020

\begin{abstract}
Polygonum plebeium is a medicinal plant, traditionally used to treat diseases associated with inflammation. The purpose of this study was to assess the anti-inflammatory effect of the aqueous methanolic extract of Polygonum plebeium (AMEPP). The plant inhibitory potential against protein denaturation was determined by measuring the absorbance of the plant extract treated with bovine serum and egg albumin solutions. The pant in vivo anti-inflammatory activity was examined by using carrageenan and egg albumin induced paw oedema models. The AMEPP has inhibited the egg albumin and bovine serum albumin denaturation $(72.99 \%$ and $67.51 \%$, respectively) dose depending. The plant extract has significantly reduced inflammation (48.7\% and 40.63\%, respectively) against carrageenan and egg albumin-induced paw oedema models. The present study concludes that the AMEPP has a promising anti-inflammatory effect which could be related to the presence of the secondary metabolites. The current study confirmed the traditional use of $P$. plebeium extract in inflammatory conditions.
\end{abstract}

\section{Rezumat}

Polygonum plebeium este folosită în mod tradițional pentru tratamentul afecțiunilor inflamatorii. Obiectivul prezentului studiu a fost de a evalua activitatea anti-inflamatoare a extractului metanolic de Polygonum plebeium. Potenţialul inhibitor împotriva denaturării proteinelor a fost determinat prin măsurarea absorbanței în domeniul UV-Vis a soluțiilor obținute prin tratarea extractului din plantă cu ser de bovine și de albumină. Activitatea anti-inflamatorie in vivo a fost evaluată folosind două modele de edem al labei induse de carrageenan (1\%) și albumină (1\%). Extractul metanolic a inhibat denaturarea albuminei de ou și a albuminei serice bovine (72,99\%, respectiv 67,51\%) într-o manieră dependentă de doză. Extractul metanolic vegetal $(500 \mathrm{mg} / \mathrm{kg})$ a redus semnificativ inflamația $(48,7 \%$ și, respectiv, $40,63 \%)$. Astfel, se poate afirma că extractul metanolic de P. plebeium are un efect antiinflamator promițător care ar putea fi atribuit prezenței metaboliților secundari, confirmând utilizarea extractului de $P$. plebeium în patologii inflamatorii.

Keywords: albumin, carrageenan, inflammation, Polygonum plebeium

\section{Introduction}

The process of inflammation has a basic function in the primary defense of the body after tissue damage or infection. It helps in restricting additional damage to the affected tissue [1]. However, chronic inflammation may be responsible for noncontagious diseases including arthritis [2]. The inflammatory response is a determinant of the autoimmune diseases, developed due to the release of various players such as leukocytes, innate lymphoid cells, and macrophages. These players are activated during inflammatory conditions and release different cytokines that activate immune cells causing tissue destruction [3].

The hunt for natural phytochemicals with potential anti-inflammatory properties is still a challenge and targeting the identification and isolation of antiinflammatory phytochemicals in plant extracts is an area of rapid growth nowadays $[4,5]$.

Herbal therapies are recommended for the management of various disorders for a long time before and more than $80 \%$ of the world population prefers herb-based medicines for its primary health care needs [6]. Pakistan is an agricultural land that has many plants traditionally used to treat 
inflammatory diseases. From the scientific study of these medicinal plants, better candidate alternative remedies for the treatment of inflammation might be evolved [7].

Polygonum plebeium R.Br, generally referred as knotweed, belongs to the family Polygonaceae. It contains various phytochemicals such as essential oils, alkaloids tannins, and flavonoids. It is largely spread in different regions of the world including Pakistan, India, Bangladesh and Sri Lanka [8]. Polygonum plebeium, is used conventionally to treat a number of disorders such as liver disease, inflammation, dysentery, eczema and ringworms [9]. However, there is no scientific data that proves the acclaimed conventional use of this plant against inflammatory conditions.

In this study, it was prompted to investigate the anti-inflammatory potential of $P$. plebeium. For this purpose, the protective effect of $P$. plebeium against bovine serum albumin and egg albumin denaturation was determined. Carageenan and egg albumin were used to induce paw oedema models, for the in vivo study. Preliminary screening of the phytochemicals in the aqueous methanolic extract of $P$. plebeium (AMEPP) was also performed.

\section{Materials and Methods}

\section{Plant material}

Polygonum plebeium was bought from a shop in Sargodha, Pakistan. The plant material was identified by Dr. Ameen, Department of Botany, University of Sargodha, Pakistan. The specimen was submitted in the herbarium and assigned a voucher number SU/Voucher/115.

\section{Extract preparation}

The whole plant material was washed thoroughly, dried, and crushed to powder form. Then, the powdered plant material (1000 g) was macerated by using $5.5 \mathrm{~L}$ of $70 \%$ methanol for 72 hours and

$$
\% \text { Inhibition }=\frac{\text { Absorbance control }- \text { Absorbance test sample }}{\text { Absorbance control }} \times 100
$$

\section{Protein denaturation by using bovine albumin}

The effect of AMEPP against bovine albumin was evaluated according to the method as previously described [12]. Briefly, the reaction mixtures were prepared by adding $0.45 \mathrm{~mL}$ of $5 \%$ of an aqueous solution of bovine albumin to $0.05 \mathrm{~mL}$ of different concentrations of plant extracts in distilled water. The $\mathrm{pH}$ was maintained at 6.3. Those mixtures were incubated for $20 \mathrm{~min}$ at $37^{\circ} \mathrm{C}$ and heated in an oven for $30 \mathrm{~min}$ at $57^{\circ} \mathrm{C}$. After that, the reaction mixtures were removed from the oven and cooled at room temperature. After cooling down, into the

$$
\% \text { Inhibition }=\frac{100-(\text { Absorbance of test sample }- \text { Absorbance of reference control })}{\text { Absorbance of test sample }} \times 100
$$

In vivo anti-inflammatory activity

Experimental animals placed at room temperature with shaking occasionally. Then it was filtered with a muslin cloth and Whatman qualitative filter paper of grade 1. It was then re-macerated two times by using aqueous methanol for another 72 hours. Then, the filtrates were collected and evaporated through the rotary evaporator at $50^{\circ} \mathrm{C}$. The final dried product was named as the aqueous methanolic extract of $P$. plebeium and stored at $-4^{\circ} \mathrm{C}$ until used for the experimental study [10]. The percentage yield was 6. $68 \%$.

Phytochemical screening

Preliminary screening of phytochemicals of AMEPP was performed for the determination of alkaloids, tannins, proteins, carbohydrates, glycoside, saponins, phenolic compounds, fixed oils and fats, gums and mucilages by using the standard procedures with slight modifications [11].

In Vitro Assays

Protein denaturation by using egg albumin

This experiment was done by preparing the reaction mixture that contains egg albumin, phosphate buffer ( $\mathrm{pH}$ 6.4) and aqueous solution at different concentrations $(6400,3200,1600,800,400,200$, 100 and $50 \mu \mathrm{g} / \mathrm{mL}$ ) of the plant extract and ibuprofen, respectively. The control reaction mixtures were prepared in the absence of the test sample by adding only $2 \mathrm{~mL}$ of distilled water at each concentration level. All the test, standard and control solutions were kept in an incubator for 15 minutes at a temperature of $37^{\circ} \mathrm{C}$. After that, these solutions were placed in an oven at $70^{\circ} \mathrm{C}$ for $5 \mathrm{~min}$. Then, the solutions were removed from the oven and scanned on a UV-Visible spectrophotometer at $660 \mathrm{~nm}$. The percentage inhibition property of the plant extract and ibuprofen were calculated from the absorbance of the solutions by using the formula [8]: test tubes containing solution,phosphate buffer saline ( $\mathrm{pH}$ 6.3) was added and the absorbance of the solutions was measured by using a UV-Visible spectrophotometer at $660 \mathrm{~nm}$. Distilled water was used as a control. Ibuprofen was used as a reference drug (50, 100, 200, 400, 800, 1600, 3200 and 6400 $\mu \mathrm{g} / \mathrm{mL}$ ). The reference and control solutions were prepared similarly as for the test sample, in the absence of the methanolic extract. Percentage inhibition of the protein denaturation was computed according to the following equation:

Sprague Dawley rats of either sex (100-200 g) have been used in this study. These animals were purchased from the University of Sargodha, 
Pakistan and acclimatized to the laboratory environment. The experimental animals were feed regularly with standard diet and water ad libitum. The protocols of this study were authorized by the Institutional Ethical Committee of University of Sargodha, Sargodha. Experimental animals were used and sacrificed according to the international procedures stated in Guide for the Care and Use of Laboratory Animals, $8^{\text {th }}$ edition.

Experimental design

Animals were distributed into 4 groups randomly (n $=5$ ). Group I was served as a negative control that received distilled water orally. Group II and III were used as a test group treated with AMEPP at a dose of 250 and $500 \mathrm{mg} / \mathrm{kg}$ bw orally, respectively. Group IV received standard drug ibuprofen (20 $\mathrm{mg} / \mathrm{kg} \mathrm{bw}$ ) orally and was considered as a standard group.

Carrageenan-induced paw edema in rats

The in vivo anti-inflammatory effect of AMEPP was evaluated by using carrageenan-induced paw edema model. The animals were then treated with their respective test samples. One-hour posttreatment, $0.1 \mathrm{~mL}$ carrageenan $(1 \% \mathrm{w} / \mathrm{v})$ was injected to animals in their sub-planter surface of the right hind paw to induce an edematous inflammation. The volume of right hind paw of each rat was measured with the help of a digital plethysmometer before the carrageenan injection $(0$ h) and at 1, 2, 3 and 4 hours after the administration of carrageenan. The edema was measured by subtracting the basal paw volume (Vo) from the inflamed paw volume in every hour by using the following formula;

Inflammation $(\mathrm{mL})=\mathrm{Vt}-\mathrm{Vo}$

Based on the volume of inflammation (oedema) for the control and test groups, the percentage inhibition was calculated according to the formula given below [13]:

$\%$ Inhibition $=\frac{\text { Inflammation }(\mathrm{mL}) \text { of } \mathrm{NC}-\text { Inflammation }(\mathrm{mL}) \text { of test group }}{\mathrm{Na}} \times 100$

Egg albumin-induced inflammatory model

Animals have fasted for 24 hours before starting the experiment. Egg albumin $(0.1 \mathrm{~mL})$ was injected to animals into the sub plantar surface of their right hind paw one-hour post-treatment. After that, volume of the paw of each animal was measured using a digital plethysmometer at zero (before

Inflammation $(\mathrm{mL})$ of each group $=\mathrm{Vt}-\mathrm{Vo}$

$$
\% \text { Inhibition }=\frac{\text { Inflammation }(\mathrm{mL}) \text { of } \mathrm{NC}-\text { Inflammation }(\mathrm{mL}) \text { of test group }}{\text { Inflammation }(\mathrm{mL}) \text { of } \mathrm{NC}} \times 100
$$

\section{Statistical analysis}

GraphPad Prism version 8 was used to analyze the data. For the in vivo activity, two-way ANOVA followed by Bonferroni's posthoc test was used for multiple comparisons. The significance level $\mathrm{p}<$ 0.05 was considered statistically significant.

\section{Results and Discussion}

Phytochemical screening

Alkaloids, tannins, saponins, phenolic compounds, proteins, carbohydrates, gums, and mucilages were detected in the AMEPP whereas, glycoside, fixed oils and fats were not detected as presented in Table I. Effect of $P$. plebeium extract on protein denaturation by using egg albumin

In vitro anti-inflammatory effect of AMEPP was evaluated at various concentrations $(6400,3200$, $1600,800,400,200,100$ and $50 \mu \mathrm{g} / \mathrm{mL})$. The plant extract inhibited egg albumin protein denaturation $(72.99 \pm 0.58)$ at the highest concentration. The plant extract exhibited a highly significant and dose-dependent anti-inflammatory activity in egg albumin protein denaturation model as shown in Table II. The effect of AMEPP was comparable to ibuprofen at all concentration levels.

Table I

Preliminary phytochemical screening of aqueous methanolic extract of $P$. plebeium

\begin{tabular}{|c|c|c|}
\hline No. & Phytochemicals & Present/Absent \\
\hline 1 & alkaloids & + \\
\hline 2 & tannins & + \\
\hline 3 & saponins & + \\
\hline 4 & Phenols & + \\
\hline 5 & proteins & + \\
\hline 6 & carbohydrates & + \\
\hline 7 & gums & + \\
\hline 8 & mucilages & + \\
\hline 9 & glycosides & - \\
\hline 10 & Fixed oils & - \\
\hline 11 & fats & - \\
\hline
\end{tabular}

Present + , Absent -

Table II

Inhibitory potential of aqueous methanolic extract of Polygonium Plebium against egg albumin protein denaturation

\begin{tabular}{|c|c|c|}
\hline Concentration $(\boldsymbol{\mu g} / \mathbf{m L})$ & Percentage inhibition by $\boldsymbol{P}$. plebeium & Percentage inhibition by Ibuprofen \\
\hline 6400 & $72.99 \pm 0.58$ & $76.48 \pm 0.32$ \\
\hline 3200 & $63.35 \pm 0.70$ & $65.22 \pm 0.54$ \\
\hline
\end{tabular}


FARMACIA, 2021, Vol. 69, 5

\begin{tabular}{|c|c|c|}
\hline Concentration $(\boldsymbol{\mu g} / \mathbf{m L})$ & Percentage inhibition by P. plebeium & Percentage inhibition by Ibuprofen \\
\hline 1600 & $63.13 \pm 0.94$ & $64.01 \pm 0.96$ \\
\hline 800 & $61 \pm 0.39$ & $60.99 \pm 0.79$ \\
\hline 400 & $55.53 \pm 0.53$ & $59.16 \pm 1.1$ \\
\hline 200 & $54.16 \pm 0.26$ & $58.91 \pm 1$ \\
\hline 100 & $41.91 \pm 0.59$ & $43.12 \pm 0.99$ \\
\hline 50 & $38.04 \pm 0.91$ & $36.99 \pm 0.76$ \\
\hline
\end{tabular}

Data were expressed as mean \pm S.D. of $n$ experiments $(n=3)$

Effect of P. plebeium on protein denaturation by using bovine albumin

Different concentrations of the plant extract and standard drug, ibuprofen, have shown a meaningful inhibitory effect $(\mathrm{p}<0.001$ compared to blank control) against bovine serum albumin denaturation
(Table III). The study indicated that AMEPP has an anti-inflammatory effect against bovine serum albumin denaturation with a maximum inhibition $(67.51 \pm 0.58)$ observed at a concentration of 6400 $\mu \mathrm{g} / \mathrm{mL}$. The standard drug ibuprofen has shown an anti-inflammatory effect with $66.44 \%$ inhibition.

Table III

The inhibitory potential of aqueous methanolic extract of Polygonium Plebium against bovine serum protein denaturation

\begin{tabular}{|c|c|c|}
\hline Concentration $(\boldsymbol{\mu g} / \mathbf{m L})$ & Percentage inhibition by $\boldsymbol{P}$. plebeium & Percentage inhibition by Ibuprofen \\
\hline 6400 & $67.51 \pm 0.58$ & $66.44 \pm 0.31$ \\
\hline 3200 & $63.75 \pm 0.7$ & $61.48 \pm 0.54$ \\
\hline 1600 & $61.42 \pm 0.94$ & $60.22 \pm 1.1$ \\
\hline 800 & $60.5 \pm 0.39$ & $58.99 \pm 0.21$ \\
\hline 400 & $54.33 \pm 0.53$ & $54.16 \pm 0.2$ \\
\hline 200 & $51.83 \pm 0.26$ & $50.33 \pm 0.45$ \\
\hline 100 & $50.2 \pm 0.19$ & $46.18 \pm 0.32$ \\
\hline 50 & $42.49 \pm 1.15$ & $40.48 \pm 0.79$ \\
\hline
\end{tabular}

Data were expressed as mean \pm S.D. of $n$ experiments $(n=3)$

Effect of P. plebeium on carrageenan-induced paw edema

The AMEPP has shown an anti-inflammatory activity in carrageenan-induced paw edema in the rat model (Table IV) which was statistically significant. Oral treatment to rats with AMEPP has decreased the level of inflammation (paw volume) in all phases as compared to the negative control. The effect of the plant extract was elevasted with the increasing dose of the plant extract against carrageenan-induced inflammation. The antiinflammatory effect of AMEPP at a dose of 250 $\mathrm{mg} / \mathrm{kg}$ bw showed a reduction in paw volume, though it was insignificant $(p<0.05)$ one-hour post carrageenan injection compared to the negative control. The anti-inflammatory property of the AMEPP (500 mg/kg bw) against carrageenaninduced oedema was relatively higher than the effect of ibuprofen, even though it was insignificant $(\mathrm{p}>0.05)$.

Table IV

Effect of the aqueous methanolic extract of $P$. plebeium on carrageenan induced paw oedema

\begin{tabular}{|c|c|c|c|c|c|}
\hline Treatment & $\begin{array}{c}0 \min (\mathrm{mL}) \\
(\% \text { inhibition })\end{array}$ & $\begin{array}{c}\text { 30min }(\mathrm{mL}) \\
(\% \text { inhibition })\end{array}$ & $\begin{array}{c}\text { 60min }(\mathrm{mL}) \\
(\% \text { inhibition })\end{array}$ & $\begin{array}{l}90 \min (\mathrm{mL}) \\
(\% \text { inhibition })\end{array}$ & $\begin{array}{l}120 \min (\mathrm{mL}) \\
(\% \text { inhibition })\end{array}$ \\
\hline Control & $0.964 \pm 0.01$ & $1.094 \pm 0.3$ & $1.214 \pm 0.02$ & $1.246 \pm 0.21$ & $1.306 \pm 0.31$ \\
\hline $\begin{array}{l}\text { Aqueous methanolic } \\
\text { extract } 250 \mathrm{mg} / \mathrm{kg} \text { bw }\end{array}$ & $0.992 \pm 0.05 \mathrm{~ns}$ & $\begin{array}{c}1.14 \pm 0.32 \mathrm{~ns} \\
(-4.2)\end{array}$ & $\begin{array}{c}1.074 \pm 0.2 \mathrm{~ns} \\
(11.53)\end{array}$ & $\begin{array}{c}0.996 \pm 0.97 * * \\
(20.06)\end{array}$ & $\begin{array}{c}0.972 \pm 0.3 * \\
(25.57)\end{array}$ \\
\hline $\begin{array}{c}\text { Aqueous methanolic } \\
\text { extract } 500 \mathrm{mg} / \mathrm{kg} \mathrm{bw}\end{array}$ & $\begin{array}{c}0.894 \pm 0.2 \mathrm{~ns} \\
(7.26)\end{array}$ & $\begin{array}{c}0.848 \pm 0.21 * * \\
(22.48)\end{array}$ & $\begin{array}{c}0.758 \pm 0.09 * * \\
(37.56)\end{array}$ & $\begin{array}{c}0.712 \pm 0.93 * * * \\
\quad(42.85)\end{array}$ & $\begin{array}{c}0.670 \pm 0.41 * * * \\
(48.7)\end{array}$ \\
\hline Ibuprofen $40 \mathrm{mg} / \mathrm{kg}$ bw & $\begin{array}{c}0.922 \pm 0.01 \mathrm{~ns} \\
(4.3)\end{array}$ & $\begin{array}{c}0.874 \pm 0.02 * * \\
(20.1)\end{array}$ & $\begin{array}{c}0.794 \pm 0.08^{* * *} \\
(34.59)\end{array}$ & $\begin{array}{c}0.752 \pm 0.76^{* *} \\
(39.64)\end{array}$ & $\begin{array}{c}0.7 \pm 0.01 * * * \\
(46.40)\end{array}$ \\
\hline
\end{tabular}

Results are expressed as means $\pm \operatorname{SEM}(\mathrm{n}=5),{ }^{*}=(\mathrm{p}<0.05),{ }^{* *}=(\mathrm{p}<0.01),{ }^{* * *}=(\mathrm{p}<0.001)$ and $\mathrm{ns}=$ non-significant when compared to control

Effect of $P$. plebeium on egg albumin-induced inflammatory model

The anti-inflammatory effect of AMEPP against egg albumin-induced oedema has been presented in Table V. The AMEPP (250 and $500 \mathrm{mg} / \mathrm{kg} \mathrm{bw}$ ) (p $<0.001)$ reduced the swelling by egg albumin at one, two, three, and four hours after inflammation. The AMEPP (500 mg/kg bw) showed the maximum inhibitory effect at $4 \mathrm{~h}$ which was $48.69 \%$ after induction of inflammation by egg albumin. 
Effect of aqueous methanolic extact of $P$. plebeium on egg albumin-induced paw oedema

\begin{tabular}{|c|c|c|c|c|c|}
\hline Treatment & $\begin{array}{l}0 \min (\mathrm{mm}) \\
(\% \text { inhibition })\end{array}$ & $\begin{array}{l}\text { 30min (mm) } \\
\text { (\%inhibition) }\end{array}$ & $\begin{array}{l}\text { 60min (mm) } \\
\text { (\%inhibition) }\end{array}$ & $\begin{array}{l}90 \min (\mathrm{mm}) \\
(\% \text { inhibition })\end{array}$ & $\begin{array}{l}120 \text { min }(\mathrm{mm}) \\
(\% \text { inhibition) }\end{array}$ \\
\hline Control & $1.128 \pm 0.02$ & $1.366 \pm 0.01$ & $1.622 \pm 0.31$ & $1.582 \pm 0.01$ & $1.570 \pm 0.31$ \\
\hline $\begin{array}{l}\text { Aqueous methanolic } \\
\text { extract } 250 \mathrm{mg} / \mathrm{kg}\end{array}$ & $\begin{array}{c}1.098 \pm 0.12 \mathrm{~ns} \\
(2.65)\end{array}$ & $\begin{array}{c}1.340 \pm 0.6 \mathrm{~ns} \\
(1.9)\end{array}$ & $\begin{array}{c}1.364 \pm 0.61^{*} \\
(15.9)\end{array}$ & $\begin{array}{c}1.252 \pm 0.41^{*} \\
(20.85)\end{array}$ & $\begin{array}{c}1.028 \pm 0.5 * * \\
(34.52)\end{array}$ \\
\hline $\begin{array}{l}\text { Aqueous methanolic } \\
\text { extract } 500 \mathrm{mg} / \mathrm{kg}\end{array}$ & $\begin{array}{c}1.020 \pm 0.03 \mathrm{~ns} \\
(9.57)\end{array}$ & $\begin{array}{c}1.182 \pm 0.97 \mathrm{~ns} \\
(13.46)\end{array}$ & $\begin{array}{c}1.094 \pm 0.34 * * \\
(32.55)\end{array}$ & $\begin{array}{c}1.026 \pm 0.43 * * \\
(35.14)\end{array}$ & $\begin{array}{c}0.932 \pm 0.39 \text { *** } \\
(40.63)\end{array}$ \\
\hline Ibuprofen 40 mg/kg & $\begin{array}{c}1.010 \pm 0.02 \mathrm{~ns} \\
(10.46)\end{array}$ & $\begin{array}{c}1.144 \pm 0.93^{*} \\
(16.25)\end{array}$ & $\begin{array}{c}1.012 \pm 0.91 * \\
(37.60)\end{array}$ & $\begin{array}{c}1.016 \pm 0.31 * * \\
(35.77)\end{array}$ & $\begin{array}{c}0.91 \pm 0.73 * * * \\
(40.03)\end{array}$ \\
\hline
\end{tabular}

The present study has been conducted to evaluate the anti-inflammatory effect of AMEPP by using the in vitro and in vivo techniques. According to the phytochemical screening performed, the aqueous methanolic extract of $P$. plebeium has comprised different phytochemicals such as saponins, alkaloids, phenols, proteins, gums, carbohydrates, tannins, and mucilages as shown in Table I. Phytochemical studies on the genus Polygonum has shown the presence of alkaloids, steroids, phenols, flavonoids, carbohydrates, tannins, sesquiterpenes, and glycosides and this class of compounds was reported to have an anti-inflammatory activity [14, 15]. Alkaloids have a variety of pharmacological activities particularly anti-proliferative as well as anti-inflammatory properties [16]. Since the major reason behind inflammation is the destruction of cells by the species of the reactive oxygen, phenolic compounds might have an outstanding radical scavenging features. Plants with the phenolic compounds have been seen to have a protective role in inflammatory conditions. $P$. plebeium contains quercetin, a strong anti-inflammatory polyphenolic compound, as reported previously $[11,17]$.

In the in vitro study, AMEPP showed inhibitory potential against egg albumin denaturation $(72.99 \%$ inhibition) and bovine albumin denaturation (67.51\% inhibition). This inhibition was dosedependently and comparable to ibuprofen as shown in Table II and III. Mostly, protein denaturation is associated with inflammation to damaged tissue and eventually causes arthritis [18].

The anti-inflammatory effect of $P$. plebeium was assessed by using carrageenan and albumin-induced paw oedema models. Carrageenan-induced paw edema model is among the most reliable model which is adequate and widely used animal model to assess the anti-inflammatory activity of the phytochemicals. Carrageenan-induced swelling is an inflammatory model of an acute condition in which there is a release of inflammatory markers that cause different signs ad symptoms of inflammation [19, 20]. The carrageenan-induced inflammation presents two separate phases of inflammation. In the first phase (first hour of inflammation), serotonin and histamine are liberated whereas in the second phase there is a release of prostaglandins after the first hour [21]. The AMEPP has significantly inhibited paw oedema $(25.57 \%$ and $48.70 \%)$ at both doses as shown in Table IV. Blockage of the synthesis and release of these inflammatory mediators may be responsible for the anti-inflammatory effect of AMEPP.

The anti-inflammatory activity of the AMEPP was also performed in egg albumin-induced inflammatory model. The aqueous methanolic extract has exhibited a statistically significant reduction $(34.52 \%$ and $40.63 \%)$ of the a paw volume at doses 250 and $500 \mathrm{mg} / \mathrm{kg}$ bw, respectively as presented in Table $\mathrm{V}$. The reduction in egg albumin-induced edema observed in the present study might explain the suppression of the synthesis, release and/or events of inflammatory mediators by the AMEPP. Histamine is a vasodilator that is responsible for the redness of a body during inflammation $[22,23]$.

\section{Conclusions}

It is concluded that the AMEPP has a promising anti-inflammatory effect which could be disbursed to the presence of the secondary metabolites. This study may justify and support the conventional use of $P$. plebeium to treat inflammatory conditions. It becomes mandatory to conduct further studies to identify and isolate the phytochemicals responsible for the anti-inflammatory activity and to elucidate their exact mechanism of action.

\section{Conflict of interest}

The authors declare no conflict of interest.

\section{References}

1. Huang $\mathrm{BP}$, Lin $\mathrm{CH}$, Chen $\mathrm{YC}$, Kao $\mathrm{SH}$, Anti-inflammatory effects of Perilla frutescens leaf extract on lipopolysaccharide-stimulated RAW264. 7 cells. Mol Med Rep., 2014; 10(2): 1077-1083.

2. Matsuda H, Morikawa T, Ando S, Toguchida I, Yoshikawa M, Structural requirements of flavonoids for nitric oxide production inhibitory 
activity and mechanism of action. Bioorg Med Chem., 2003; 11(9): 1995-2000.

3. Shi G, Zhang J, Zhang ZJ, Zhang X, Systemic autoimmune diseases. J Immunol Res., 2015; 2015:183591: 1-2.

4. Bello AE, Holt RJ, Cardiovascular risk with nonsteroidal anti-inflammatory drugs: clinical implications. Drug Saf., 2014; 37(11): 897-902.

5. Humulescu I, Lungu II, Cioancă O, Sava AR, Buciscanu I, Robu S, Toma C, Hăncianu $M$, Morphological features of Romanian endemic Teucrium L. species. Rev Med Chir Soc Med Nat Iasi, 2020; 124(1): 157-162.

6. Hintsa G, Sibhat GG, Karim A, Evaluation of Antimalarial Activity of the Leaf Latex and TLC Isolates from Aloe megalacantha Baker in Plasmodium berghei Infected Mice. Evid Based Complement Alternat Med., 2019; 2019: 6459498: 1-9.

7. Choudhary M, Kumar V, Malhotra H, Singh S, Medicinal plants with potential anti-arthritic activity. J Intercult Ethnopharmacol., 2015; 4(2): 147-179.

8. Hasan A, Roy P, Bristy NJ, Paul SK, Wahed TB, Alam MN, Evaluation of in vitro antioxidant and brine shrimp lethality bioassay of different extracts of Polygonum plebeium R. Br. Int J Adv Res., 2015; 3(12): 97-107.

9. Uttra AM, Ahsan H, Hasan UH, Chaudhary M, Traditional medicines of plant origin used for the treatment of inflammatory disorders in Pakistan: A review. J Trad Chinese Med., 2018; 38(4): 636656.

10. Alamgeer NH, Rasool S, Raza SA, Ahmad T, Ahsan H, Mushtaq MN, Anti-inflammatory, analgesic and antipyretic activities of the aqueous methanolic extract of Berberis calliobotrys in albino mice. Acta Pol Pharm., 2016; 73: 717-723.

11. Banu KS, Cathrine LJ, General techniques involved in phytochemical analysis. Int J Adv Res Chem Sci., 2015; 2(4): 5-32.

12. Rahman $\mathrm{H}$, Eswaraiah $\mathrm{M}$, Vakati $\mathrm{K}$, Madhavi $\mathrm{P}$, In vitro studies suggest probable mechanism of eucalyptus oil for anti-inflammatory and antiarthritic activity. Int J Phyto Pharm., 2012; 2: 8183.

13. Ocete M, Risco S, Zarzuelo A, Jimenez J, Pharmacological activity of the essential oil of
Bupleurum gibraltaricum: anti-inflammatory activity and effects on isolated rat uteri. $J$ Ethnopharmacol., 1989; 25(3): 305-313.

14. Gou KJ, Zeng R, Dong Y, Hu QQ, Hu HW, Maffucci KG, Dou QL, Yang QB, Qin XH, Qu Y, Anti-inflammatory and analgesic effects of Polygonum orientale L. extracts. Front Pharmacol., 2017; 8: 562: 1-13.

15. Gowri R, Madhavan V, Phytochemical and AntiInflammatory Activity of Polygonum barbatum. $J$ Dent \& Oro-fac Res., 2018; 14(2): 45-48.

16. Jeong DH, Lee GP, Jeong WI, Do SH, Yang HJ, Yuan DW, Park HY, Kim KJ, Jeong KS, Alterations of mast cells and TGF-beta1 on the silymarin treatment for $\mathrm{CCl}(4)$-induced hepatic fibrosis. World J Gastroenterol., 2005; 11(8): 1141-1148.

17. Hao C, Manzhi G, Yilin F, Hang L, Determination of Quercetin in Polygonum plebeium R. Br. by HPLC. China Pharm., 2013(3): 28.

18. Rea IM, Gibson DS, McGilligan V, McNerlan SE, Alexander HD, Ross OA, Age and age-related diseases: role of inflammation triggers and cytokines. Neurosci., 2018; 9: 586: 1-28.

19. Scapinello J, Müller LG, Schindler MS, Anzollin GS, Siebel AM, Boligon AA, et al, Antinociceptive and anti-inflammatory activities of Philodendron bipinnatifidum Schott ex Endl (Araceae). J Ethnopharmacol., 2019; 236: 21-30.

20. Sharma BR, Park CM, Choi JW, Rhyu DY, Antinociceptive and anti-inflammatory effects of the methanolic extract of Opuntia humifusa stem. Avicenna J Phytomed., 2017; 7(4): 366-375.

21. Silva GN, Martins FR, Matheus ME, Leitão SG, Fernandes PD, Investigation of anti-inflammatory and antinociceptive activities of Lantana trifolia. $J$ Ethnopharmacol., 2005; 100(3): 254-259.

22. Ojewole JA, Antinociceptive, anti-inflammatory and antidiabetic effects of Bryophyllum pinnatum (Crassulaceae) leaf aqueous extract. $J$ Ethnopharmacol., 2005; 99(1): 13-19.

23. Adedapo AA, Sofidiya MO, Maphosa V, Moyo B, Masika PJ, Afolayan AJJ, Anti-inflammatory and analgesic activities of the aqueous extract of Cussonia paniculata stem Bark. Rec Nat Pro., 2008; 2(2): 46-53. 